\title{
Evaluation of inflammatory markers in patients with migraine
}

\section{Migren hastalarında enflamatuvar belirteçlerin değerlendirilmesi}

\author{
Aysel Tekeşin ${ }^{1}$, Abdülkadir Tunç ${ }^{2}$
}

\section{Abstract}

Aim: The aim of this study was to evaluate erythrocyte sedimentation rate (ESR), high sensitivity C-reactive protein (hsCRP), neutrophil-to-lymphocyte ratio (NLR), monocyte to HDL-C ratio (MHR), and bilirubin levels in patients with migraine and compare with levels measured in healthy subjects.

Methods: This retrospective case-control study included 136 migraine patients and 80 healthy controls who were admitted to our neurology outpatient clinic or emergency between June 2017 and June 2018. Laboratory examinations, disease characteristics, presence of aura, and the presence of white matter hyperintensities (WMHs) were recorded and demographic features and laboratory data were compared between two groups. Results: The mean age of the case group was $36.9 \pm 10.6$ years and the control group was $37 \pm 12$ years. In the patient group, total bilirubin, direct bilirubin, indirect bilirubin, and lymphocyte values were significantly lower than the control group. NLR, hsCRP, and ESR levels were significantly higher in the patient group than the control group. The patient and control groups did not show a significant difference according to the presence of WMHs. In the group with aura, monocyte and MHR values were higher than those without aura. The hsCRP values in the group with aura were significantly lower than the group without aura.

Conclusion: This study showed that low bilirubin and high NLR, MHR, hsCRP, and ESR values might be potential inflammatory markers in migraine patients. These markers may contribute to our understanding of the pathophysiology of migraine. Since the cost of these tests is cheap and they are widely used, it is possible to believe that they may be useful for protecting migraine patients against long-term comorbidities.

Keywords: Migraine, inflammation, laboratories, biomarker

Öz

Amaç: Bu çalışmanın amacı migren hastalarında eritrosit sedimentasyon hızı (ESR), yüksek duyarlılıklı Creaktif protein (hsCRP), nötrofil-lenfosit oranı (NLO), monosit-HDL-C oranı (MHO) ve bilirubin düzeylerinin değerlendirilmesi ve sağlıklı bireylerde ölçülen seviyelerle karşılaştırılmasıdır.

Yöntemler: Bu retrospektif vaka-kontrol çalıșmasına Haziran 2017-Haziran 2018 tarihleri arasında hastanemiz nöroloji polikliniğine veya acil servisine başvuran 136 migren hastası ve 80 sağlıklı kontrol dahil edildi. Tüm katılımcıların laboratuvar tetkikleri, hastalık özellikleri, aura varlığı ve beyaz cevher lezyonlarının varlığ kaydedildi ve demografik özellikler ve laboratuvar verileri iki grup arasında karşılaştırıldı.

Bulgular: Vaka grubunun yaş ortalaması $36.9 \pm 10.6$ yıl ve kontrol grubunun $37 \pm 12$ yıl idi. Hasta ve kontrol grupları arasında yaş ve cinsiyet açısından anlamlı fark saptanmadı. Vaka grubunda total bilirubin, direk bilirubin, indirekt bilirubin, lenfosit değerleri kontrol grubuna göre anlamlı derecede düşüktü. Hasta grubunda NLO, hsCRP, ESR düzeyleri kontrol grubuna göre anlamlı yüksekti. Vaka ve kontrol grupları beyaz cevher lezyonları varlığı açısından anlamlı farklılık göstermedi. Aurası olan ve olmayan migren hastalarında yaş, cinsiyet, total bilirubin, direkt bilirubin ve indirekt bilirubin değerleri, NLO, ürik asit, lenfosit ve ESR düzeyleri açısından anlamlı fark saptanmadı. Auralı grupta monosit ve MHO değerleri aurasız gruba göre yüksekti. Auralı grupta hsCRP değeri aurasız gruba göre istatistiksel olarak anlamlı düşüktü.

Sonuç: Bu çalışma, migren hastalarında düşük bilirubin ve yüksek NLO, CRP ve ESR değerlerinin potansiyel enflamatuvar marker olabileceğini göstermiştir. Bu markerlar hastalığın patofizyolojisini anlamamıza katkıda bulunabilir. Ayrıca söz konusu testlerin maliyeti ucuz ve yaygın kullanılan tetkikler olduğundan özellikle migren hastalarını olası uzun dönem komorbiditelerden korumak açısından faydalı olabileceği görüşündeyiz. Anahtar Kelimeler: Migren, enflamasyon, laboratuvar, biyomarker
1 Health Sciences University, Istanbul Training and Research Hospital, Clinic of Neurology, Istanbul, Turkey.

${ }^{2}$ Sakarya University, Sakarya Training and Research Hospital, Clinic of Neurology, Sakarya, Turkey.

Ethics Committee Approval: The study wass approved by the local ethical authority.

Etik Kurul Onayı: Çalışma lokal etik komite tarafindan onaylanmıştır.

Conflict of Interest: No conflict of interest was declared by the authors.

Cııar Çatışması: Yazarlar çıkar çatışması bildirmemişlerdir.

Financial Disclosure: The authors declared that this study has received no financial support.

Finansal Destek: Yazarlar bu çalışma için finansal destek almadıklarını beyan etmișlerdir.

Geliş Tarihi / Received: 10.12.2018

Kabul Tarihi / Accepted: 25.02.2019

Yayın Tarihi / Published: 15.03.2019

Sorumlu yazar / Corresponding author:

Abdulkadir TUNC

Adres/Address: Sakarya University, Sakarya

Training and Research Hospital, Clinic of Neurology, Sakarya, Turkey

e-posta: drkadirtunc@hotmail.com

Tel/Phone: (+90) 5545144524

Copyright $\odot$ ACEM 


\section{Introduction}

Migraine is a common, multifactorial primary headache disorder. It is characterized by recurrent throbbing headache, nausea, and sensitivity to stimulants such as sound, light, and movement [1]. The prevalence ranges from $5 \%$ to $20 \%$ in the general population [2]. Although the pathophysiology is still debatable, it's thought that some peptides (e.g., substance P, calcitonin gene-related peptide, and neurokinin A) are released from the perivascular trigeminal regions after the activation of the brain tissue; that caused inflammation and dilation of the extraparenchymal vessels [3].

Erythrocyte sedimentation rate (ESR) and high sensitivity C-reactive protein (hsCRP) are the most widely used inflammatory markers in current clinical practice $[4,5]$. The neutrophil-to-lymphocyte ratio (NLR) was reported to be novel inflammatory biomarkers in patients with Guillain-Barré syndrome and venous thrombosis [6, 7]. Increased monocyte counts and decreased HDL-cholesterol (HDL-C) levels were also found to be associated with inflammation, and monocyte to HDL-C ratio (MHR) was suggested to be used as a potential inflammatory biomarker [8, 9]. A significant relationship was shown between high bilirubin levels and antiinflammation in various diseases [10].

Therefore, in this study we aimed to evaluate ESR, hsCRP, NLR, MHR, and bilirubin levels in patients with migraine and compare with levels measured in healthy subjects. Secondly, their relationship with the presence of aura and cranial magnetic resonance imaging (MRI) findings were evaluated.

\section{Material and methods}

This retrospective case-control study included 136 migraine patients and 80 healthy controls aged between 16 and 66 years, who were admitted to our neurology outpatient clinic or emergency between June 2017 and June 2018.

It was approved by our local ethics committee. An informed written consent was taken from all the participants. All procedures performed in studies involving human participants were in accordance with the ethical standards of the institutional and/or national research committee and with the 1964 Helsinki declaration and its later amendments or comparable ethical standards. The inclusion criterion for migraine patients was the diagnosis of migraine according to the International Classification of Headache Disorders III (beta version) (ICHDIII) [11]. Exclusion criterion were as follows: other ICHD-III diagnosis (e.g., tension type headache, cluster headache etc.); pregnancy/puerperium, any systemic diseases, neurological disorders, inflammatory diseases or any other condition that can affect the inflammatory biomarkers, and the patients under medical treatment with any antiinflammatory medications.

The control group was selected among the relatives of the migraine patients, hospital employees, or the general population. Written informed consent was obtained from them for voluntary participation in the study. The inclusion criteria for the control group were as follows: absence of migraine, the maximum frequency of any headache less than 1 episode per month (e.g., tension type headache, or any other type of chronic headache). Exclusion criteria for the healthy controls were the same as those for the migraine patients.

The blood samples were obtained by careful venipuncture during emergency or outpatient clinic admission before medical treatments. Samples for hematological tests were collected in EDTA tubes, and in dry tubes for biochemical tests. The laboratory investigations included serum hemogram, full biochemistry profiles including HDL, bilirubins, hsCRP, and ESR, which were measured using automated standard laboratory methods. Automated hematology analyzer XE-1200 (Sysmex, Kobe, Japan) was used for complete blood count's measurements. A molecular analyzer (Roche Diagnostics, Manheim, Germany) was used for the biochemical measurements. Hs-CRP measurement was done using an automatized analyser (Beckman Coulterw IMMAGE) using nephelometric measurement.

Demographic features, laboratory examinations, disease characteristics, presence of aura, brain MRI findings were recorded. A computerized database was used to collect the laboratory data. NLR and MHR ratios were calculated and compared between the patients and healthy subjects.

\section{Statistical Analysis}

The data were transferred into the IBM SPSS Statistics 22.0 program and the analyses were completed. Mean, standard deviation, median, lowest- highest, frequency and ratio were included in the descriptive statistics of the data. The distribution of the variables was measured by the Kolmogorov-Smirnov test. Independent sample $t$ test, and Mann-Whitney $U$ test were used in the analysis of quantitative independent data. A chi-square test was applied to analyze the significance of the multiple comparison of relative frequencies among the groups, and Fischer test was used when chi-square test did not meet the conditions. Spearman correlation analysis was used for correlation analysis. The limit for statistical significance was accepted as $\mathrm{p}<0.05$.

\section{Results}

The mean age of the case group was $36.9 \pm 10.6$ years and the control group was $37 \pm 12$ years. No significant difference was found between the patient and control groups in terms of age and gender. In the patient group, total bilirubin (TB), direct bilirubin (DB), indirect bilirubin (IB) and lymphocyte values were significantly lower than the control group $(\mathrm{p}=0.001, \mathrm{p}=$ $0.005, \mathrm{p}=0.001$, and $\mathrm{p}=0.001$, respectively). NLR, hsCRP, and ESR levels were significantly higher in the patient group $(\mathrm{p}=$ $0.001, \mathrm{p}=0.001$, and $\mathrm{p}=0.001$, respectively).

The patient and control groups did not show a significant difference according to the presence of white matter hyperintensities (WMHs) $(\mathrm{p}=0.320)$ (Table 1$)$. There was no significant difference in terms of age, gender, total bilirubin, direct bilirubin, and indirect bilirubin values, NLR, uric acid, lymphocyte, and ESR levels in patients with and without aura $(\mathrm{p}>0.05)$. In group with aura (MwA), monocyte and MHR values were higher than those migraine patients without aura (MwoA) $(\mathrm{p}=0.002, \mathrm{p}=0.013)$. The hsCRP values in the MwA group were significantly lower than the MwoA group $(\mathrm{p}=0.026)$ (Table 2).

\section{Discussion}

Our study revealed that inflammation may be connected with the pathogenesis of migraine. ESR, hsCRP, and NLR values were significantly higher and bilirubin, and lymphocyte values were significantly lower in migraine patients compared with the healthy subjects in this study. Monocyte and MHR values were higher in MwA patients.

It has been revealed that migraine pathogenesis is strongly related to the neurogenic inflammation [12]. In the literature, it has also been demonstrated that a significant association is detected between migraine and cardiovascular

$\mathrm{P}$ a g e / S a y f a 38 
Table 1. Evaluation of demographic and laboratory findings in migraine patients and healthy controls.

\begin{tabular}{|c|c|c|c|}
\hline & Controls $(n=80)$ & Patients $(n=136)$ & $\mathrm{P}$ \\
\hline Age $(\text { year })^{\beta}$ & $37 \pm 12$ & $36.9 \pm 10.6$ & 0.823 \\
\hline Gender $^{\mp}$ & & & 0.140 \\
\hline Female & $70(87.5)$ & $127(93.4)$ & \\
\hline Male & $10(12.5)$ & $9(6.6)$ & \\
\hline Smoking $^{¥}$ & & & 0.453 \\
\hline No & $69(86.3)$ & $112(82.4)$ & \\
\hline Yes & $11(13.8)$ & $24(17.6)$ & \\
\hline Alcohol $^{¥}$ & & & 0.531 \\
\hline No & $80(100)$ & $134(98.5)$ & \\
\hline Yes & $0(0)$ & $2(1.5)$ & \\
\hline Presence of $\mathrm{WMHs}^{*}$ & & & 0.320 \\
\hline No & $73(91.3)$ & $118(86.8)$ & \\
\hline Yes & $7(8.8)$ & $18(13.2)$ & \\
\hline Lesion count $(\mathrm{n})^{\beta}$ & $5.86 \pm 5.08$ & $4.39 \pm 3.93$ & 0.409 \\
\hline Uric Acid $(\mathrm{mg} / \mathrm{dL})^{\beta}$ & $3.87 \pm 0.79$ & $4.05 \pm 1.15$ & 0.151 \\
\hline Total Bilirubin $(\mathrm{mg} / \mathrm{dL})^{\beta}$ & $0.89 \pm 0.36$ & $0.60 \pm 0.34$ & 0.001 \\
\hline Direct Bilirubin $(\mathrm{mg} / \mathrm{dL})^{\beta}$ & $0.16 \pm 0.07$ & $0.14 \pm 0.09$ & 0.005 \\
\hline Indirect Bilirubin $(\mathrm{mg} / \mathrm{dL})^{\beta}$ & $0.74 \pm 0.31$ & $0.46 \pm 0.27$ & 0.001 \\
\hline Neutrophil count $\left(\times 10^{3} / \mu 1\right)^{\beta}$ & $4.12 \pm 1.30$ & $4.27 \pm 1.46$ & 0.697 \\
\hline Lymphocyte count $\left(\times 10^{3} / \mu 1\right)^{\beta}$ & $2.66 \pm 0.71$ & $2.26 \pm 0.67$ & 0.001 \\
\hline Monocyte count $\left(\times 10^{3} / \mu 1\right)^{\beta}$ & $0.52 \pm 0.16$ & $0.50 \pm 0.18$ & 0.252 \\
\hline Neutrophil/Lymphocyte ${ }^{\beta}$ & $0.61 \pm 0.69$ & $2.16 \pm 2.15$ & 0.001 \\
\hline Monocyte/HDL ${ }^{\beta}$ & $0.011 \pm 0.004$ & $0.01 \pm 0.004$ & 0.080 \\
\hline $\operatorname{hsCRP}(\mathrm{mg} / \mathrm{L})^{\beta}$ & $0.34 \pm 0.23$ & $0.58 \pm 0.41$ & 0.001 \\
\hline $\mathrm{HDL}(\mathrm{mg} / \mathrm{L})^{\beta}$ & $50.5 \pm 12.7$ & $53.1 \pm 11.6$ & 0.072 \\
\hline $\operatorname{ESR}(\mathrm{mm} / \mathrm{h})^{\beta}$ & $14.0 \pm 8.2$ & $20.5 \pm 10.2$ & 0.001 \\
\hline
\end{tabular}

${ }^{*}: \mathrm{n}(\%),{ }^{\beta:}$ Mean \pm standard deviation

ESR: Erythrocyte sedimentation rate; HDL: High density lipoprotein; hsCRP:

High sensitivity C-reactive protein; WMHs: White matter hyperintensities.

disease, stroke, and atherosclerosis, and a causal link has been put forward between migraine attacks and inflammatory arteriopathy of the brain vessels [13, 14]. Emerging evidences about the migraine pathogenesis showed that several cytokines mainly IL-6, TNF, and IL-10 are involved, wherein sensitization of nerve endings can be promoted by these inflammatory cytokines during recurrent migraine attacks $[15,16]$. Moreover, increased CRP values have been demonstrated to be related to migraine, and have been considered to be an inflammatory marker in migraine patients [17]. Consistent with these studies, our study revealed an increased serum concentration of ESR and hsCRP levels in patients with migraine compared with healthy individuals.

Interestingly, lower levels of $\mathrm{TB}, \mathrm{DB}$, and $\mathrm{IB}$ were found in migraine patients, and a negative correlation between CRP and bilirubin levels was detected in a study of Peng et al [18]. In another earlier trial, serum bilirubin was exhibited an antiinflammatory property and was shown to be stronger than other antioxidants [19]. In support of this, our study observed lower bilirubin levels in migraine patients. An overconsumption of bilirubin by neurogenic inflammation may be responsible from these physiological phenomenon.

The NLR is a simply calculated biomarker from the lymphocyte and neutrophil counts in the venous blood samples. It was investigated in several studies and elevated levels were shown to be important biomarker in coronary artery diseases [20, 21]. The role of MHR in predicting inflammation has been demonstrated by limited number of studies [22, 23]. It has been shown to be an independent predictor of cardiovascular events in chronic renal failure patients and poor prognosis for cardiovascular mortality [9]. Our study showed higher levels of NLR in migraine patients. On the other hand, monocyte and MHR values were significantly higher in MwA patients. In the literature, some inflammatory biomarkers such as high leptin, Soluble urokinase plasminogen activator receptor, apolipoprotein $\mathrm{E}$, and CRP levels were found to be increased in MwA patients supporting the inflammatory hypothesis [24-27]. Further studies with serum markers and inflammatory citokines are needed to evaluate the possible relationship.

Table 2. Evaluation of demographic and laboratory findings of the MwA and MwoA patients.

\begin{tabular}{|c|c|c|c|}
\hline & $\begin{array}{c}\text { Aura (-) } \\
(\mathrm{n}=95)\end{array}$ & $\begin{array}{c}\text { Aura (+) } \\
(n=41)\end{array}$ & $\mathrm{P}$ \\
\hline Age $($ mean \pm sd $)$ & $36.4 \pm 10.2$ & $38.1 \pm 11.5$ & 0.413 \\
\hline Gender ${ }^{*}$ & & & 0.198 \\
\hline Female & 87 (91.6) & $40(97.6)$ & \\
\hline Male & $8(8.4)$ & $1(2.4)$ & \\
\hline Smoking $^{¥}$ & & & 0.908 \\
\hline No & $78(82.1)$ & $34(82.9)$ & \\
\hline Yes & $17(17.9)$ & $7(17.1)$ & \\
\hline Alcohol $^{¥}$ & & & 1.000 \\
\hline No & $93(97.9)$ & $41(100)$ & \\
\hline Yes & $2(2.1)$ & $0(0)$ & \\
\hline Presence of WMHs ${ }^{*}$ & & & 0.356 \\
\hline No & $84(88.4)$ & $34(82.9)$ & \\
\hline Yes & $11(11.6)$ & $7(17.1)$ & \\
\hline Lesion count $^{\beta}$ & $4.45 \pm 4.13$ & $4.29 \pm 3.90$ & 0.963 \\
\hline Right Localisation ${ }^{¥}$ & $32(33.7)$ & $16(39)$ & \\
\hline Left localisation ${ }^{¥}$ & $21(22.1)$ & $7(17.1)$ & 0.747 \\
\hline Bilateral localisation $^{¥}$ & $42(44.2)$ & $18(43.9)$ & \\
\hline Migraine duration, (year) ${ }^{\beta}$ & $7.3 \pm 4.8$ & $6.8 \pm 6.6$ & 0.161 \\
\hline Attack frequency, (month) ${ }^{\beta}$ & $3.6 \pm 2.5$ & $4.1 \pm 3.4$ & 0.814 \\
\hline Attack duration, (hour) ${ }^{\beta}$ & $14.6 \pm 15.3$ & $28.0 \pm 22.6$ & 0.002 \\
\hline Uric Acid $(\mathrm{mg} / \mathrm{dL})^{\beta}$ & $4.00 \pm 1.04$ & $4.15 \pm 1.36$ & 0.699 \\
\hline Total Bilirubin $(\mathrm{mg} / \mathrm{dL})^{\beta}$ & $0.60 \pm 0.34$ & $0.58 \pm 0.33$ & 0.368 \\
\hline Direct Bilirubin $(\mathrm{mg} / \mathrm{dL})^{\beta}$ & $0.15 \pm 0.10$ & $0.12 \pm 0.06$ & 0.089 \\
\hline Indirect Bilirubin $(\mathrm{mg} / \mathrm{dL})^{\beta}$ & $0.46 \pm 0.27$ & $0.46 \pm 0.27$ & 0.608 \\
\hline Neutrophil count $\left(\times 10^{3} / \mu 1\right)^{\beta}$ & $4.19 \pm 1.52$ & $4.46 \pm 1.30$ & 0.111 \\
\hline Lymphocyte count $\left(\times 10^{3} / \mu 1\right)^{\beta}$ & $2.22 \pm 0.68$ & $2.36 \pm 0.62$ & 0.279 \\
\hline Monocyte count $\left(\times 10^{3} / \mu 1\right)^{\beta}$ & $0.47 \pm 0.14$ & $0.58 \pm 0.21$ & 0.002 \\
\hline Neutrophil/Lymphocyte ${ }^{\beta}$ & $2.21 \pm 2.51$ & $2.03 \pm 0.88$ & 0.676 \\
\hline Monocyte/HDL ${ }^{\beta}$ & $0.009 \pm 0.004$ & $0.012 \pm 0.005$ & 0.013 \\
\hline $\mathrm{hsCRP}(\mathrm{mg} / \mathrm{L})^{\beta}$ & $0.63 \pm 0.41$ & $0.48 \pm 0.40$ & 0.026 \\
\hline $\operatorname{HDL}(\mathrm{mg} / \mathrm{L})^{\beta}$ & $53.0 \pm 11.2$ & $53.4 \pm 12.7$ & 0.917 \\
\hline $\operatorname{ESR}(\mathrm{mm} / \mathrm{h})^{\beta}$ & $21.6 \pm 10.6$ & $18.0 \pm 9.0$ & 0.064 \\
\hline
\end{tabular}

${ }^{*}: \mathrm{n}(\%),{ }^{\beta:}$ Mean \pm standard deviation

ESR: Erythrocyte sedimentation rate; HDL: High density lipoprotein; hsCRP

High sensitivity C-reactive protein; WMHs: White matter hyperintensities.

An association between MwA and WMHs was shown in most of the previous studies [28, 29]. Contrary, there was no significant differences in terms of presence and number of WMHs between migraine patients and healthy controls. That might be due to low number of patients in our study.

Our study had some limitations. First, the number of patients were relatively low. Second, the correlation between evaluated serum markers and inflammatory cytokines such as IL6, IL-10, and TNF were not analyzed. It was unclear whether these biomarkers and systemic inflammation had a causative relationship. Third, body mass index and disease duration were not evaluated, and finally, evaluation of oxidative stress biomarkers would be more precious.

This study showed that low bilirubin and high NLR, MHR, hsCRP, and ESR values might be potential inflammatory markers in migraine patients. These markers may contribute to our understanding of the pathophysiology of migraine. In addition, since the cost of these tests is cheap and they are widely used, it is possible to believe that they may be useful for protecting migraine patients against long-term comorbidities.

\section{References}

1. Burstein R, Noseda R, Borsook D. Migraine: multiple processes, complex pathophysiology. J Neurosci. 2015;35:6619-29.

2. Lipton RB, Bigal ME. Migraine: epidemiology, impact, and risk factors for progression. Headache. 2005;45:3-13.

3. Sinclair AJ, Matharu M. Migraine, cerebrovascular disease and the metabolic syndrome. Ann Indian Acad Neurol. 2012;15:72-7.

4. Nagai M, Terao S, Yilmaz G, Yilmaz CE, Esmon CT, Watanabe E, et al Roles of inflammation and the activated protein $\mathrm{C}$ pathway in the brain edema associated with cerebral venous sinus thrombosis. Stroke. 2010;41:147-52 
5. Ammirati E, Moroni F, Norata GD, Magnoni M, Camici PG. Markers of inflammation associated with plaque progression and instability in patients with carotid atherosclerosis. Mediators Inflamm. 2015;2015:718329.

6. Ozdemir HH. Analysis of the albumin level, neutrophil-lymphocyte ratio, and platelet-lymphocyte ratio in Guillain-Barré syndrome. Arq Neuropsiquiatr. 2016;74:718-22.

7. Artoni A, Abbattista M, Bucciarelli P, Gianniello F, Scalambrino E, Pappalardo E, et al. Platelet to Lymphocyte Ratio and Neutrophil to Lymphocyte Ratio as Risk Factors for Venous Thrombosis. Clin Appl Thromb Hemost. 2018;24:808-14.

8. Ciçek G, Kundi H, Bozbay M, Yayla C, Uyarel H. The relationship between admission monocyte HDL-C ratio with short-term and longterm mortality among STEMI patients treated with successful primary PCI. Coron Artery Dis. 2016;27:176-84.

9. Kanbay M, Solak Y, Unal HU, Kurt YG, Gok M, Cetinkaya H, et al. Monocyte count/HDL cholesterol ratio and cardiovascular events in patients with chronic kidney disease. Int Urol Nephrol. 2014;46:161925.

10. Kapitulnik J. Bilirubin: An endogenous product of heme degradation with both cytotoxic and cytoprotective properties. Mol Pharmacol. 2004;66:773-9.

11. Headache Classification Subcommittee of the International Headache Society. The international classification of headache disorders: 3rd edition (beta version). Cephalalgia. 2013;33:629-808.

12. Spierings EL. Pathogenesis of the migraine attack. Clin J Pain 2003; 19:255-62.

13. Yetkin E, Ozisik H, Ozcan C, Aksoy Y, Turhan H. Decreased endothelium-dependent vasodilatation in patients with migraine: A new aspect to vascular pathophysiology of migraine. Coron Artery Dis 2006:17:29-33.

14. Avci AY, Lakadamyali H, Arikan S, Benli US, Kilinc M. High sensitivity C-reactive protein and cerebral white matter hyperintensities on magnetic resonance imaging in migraine patients. J Headache Pain. 2015;16:9.

15. Wang F, He Q, Ren Z, Li F, Chen W, Lin X, et al.Association of serum levels of intercellular adhesion molecule-1 and interleukin-6 with migraine. Neurol Sci. 2015;36:535-40.

16. Liu R, Ma M, Cui M, Dong Z, Wang X, Zhang W, et al. Effects of tumor necrosis factor- $\beta$ (TNF- $\beta$ ) $252 \mathrm{~A}>\mathrm{G}$ polymorphism on the development of migraine: a meta-analysis. PLoS One. 2014;9:e100189.

17. Lippi G, Mattiuzzi C, Cervellin G. C- reactive protein and migraine. Facts or speculations? Clin Chem Lab Med. 2014;52:1265-72.

18. Peng YF, Xie LQ, Xiang Y, Xu GD. Serum Bilirubin and Their Association With C-Reactive Protein in Patients With Migraine. J Clin Lab Anal. 2016;30:982-5.

19. Stocker R, Yamamoto Y, McDonagh AF, Glazer AN, Ames BN Bilirubin is an antioxidant of possible physiological importance. Science. 1987;235:1043-6.

20. Nunez J, Nunez E, Bodi V, Sanchis J, Miñana G, Mainar L, et al. Usefulness of the neutrophil to lymphocyte ratio in predicting long-term mortality in ST segment elevation myocardial infarction. Am J Cardiol. 2008;101:747-52.

21. Yuksel M, Yildiz A, Oylumlu M, Akyüz A, Aydın M, Kaya H, et al The association between platelet/lymphocyte ratio and coronary artery disease severity. Anatol J Cardiol. 2015;15:640-7.

22. Rezende SM, Lijfering WM, Rosendaal FR, Cannegieter SC. Hematologic variables and venous thrombosis: red cell distribution width and blood monocyte count are associated with an increased risk. Haematologica. 2014;99:194-200.

23. Efe TH, Arslan ED, Ertem AG, Yayla Ç, Felekoğlu MA, İnci S, et al. The prognostic value of the monocyte/hdl ratio in predicting short-term mortality in patients with acute pulmonary embolism. Koşuyolu Heart Journal. 2016;19:149-53.

24. Pisanu C, Preisig M, Castelao E, Glaus J, Cunningham JL, Del Zompo $\mathrm{M}$, et al. High leptin levels are associated with migraine with aura Cephalalgia. 2017;37:435-41.

25. Yilmaz N, Yilmaz M, Sirin B, Yılmaztekin S, Kutlu G. The relationship between levels of plasma-soluble urokinase plasminogen activator receptor (suPAR) and presence of migraine attack and aura. J Recept Signal Transduct Res. 2017;37:447-52.

26. Yuasa N, Nagata E, Fujii N, Ito M, Tsukamoto H, Takizawa S. Serum apolipoprotein E may be a novel biomarker of migraine. PLoS One. 2018;13:e0190620.

27. Lippi G, Mattiuzzi C, Cervellin G. C-reactive protein and migraine. Facts or speculations? Clin Chem Lab Med. 2014;52:1265-72.

28. Tunç A, Tekeşin AK, Güngen BD, Arda E. Cognitive performance in young and middle-aged adults with migraine: Investigating the correlation with white matter hyperintensities and psychological symptoms. Neurol Neurochir Pol. 2018;52:470-6.

29. Bashir A, Lipton RB, Ashina S, Ashina M. Migraine and structural changes in the brain: a systematic review and meta-analysis. Neurology. 2013;81:1260-8. 